\title{
NEW ZEALAND'S OMBUDSMEN \\ LEGISLATION: THE NEED FOR \\ AMENDMENTS AFTER ALMOST 50 YEARS
}

\author{
Mai Chen*
}

It has been almost fifty years since the original Parliamentary Commissioner (Ombudsman) Act was passed in 1962, the precursor to the current Ombudsmen Act 1975. Since that time, the role has expanded significantly and the constitutional framework in which the Ombudsman operates has also changed significantly, yet the legislation has never undergone a thorough review. In this article, Mai Chen examines how Ombudsmen are a key tool in the Public Law Toolbox. She reviews the functions of the Office, showing that it can be more effective than courts in addressing issues of public administration in some circumstances, due to its accessibility, low cost to the complainant, and range of remedies available. The article concludes that as so much of the Ombudsmen's work is in private, the lack of formal use of statutory powers to compel or to make formal recommendations may actually evidence their effectiveness in using persuasion to get those complained about to redress the problem. Ms Chen makes a number of reform proposals to reflect recent developments, and to allow the Office to fulfil its constitutional role including a specific public education function, a 20 working day deadline on providing the Ombudsmen with any information requested, a presumption of jurisdiction for bodies exercising public powers affecting the public and which are publicly funded, an express power to comment on law-making with implications for the Ombudsmen and Official Information Acts, extending jurisdiction to "committees of the whole" in Local Government, and a single fixed term to protect Ombudsmen independence in office. The article also

* Partner, Chen Palmer New Zealand Public Law Specialists. Thanks to Sir Kenneth Keith for helpful comments, and to Eesvan Krishnan for editing suggestions. I also acknowledge the research assistance of Richard Harker, Intermediate Associate at Chen Palmer, and the assistance of Chief Ombudsman Beverly Wakem, Ombudsman David McGee QC, Assistant Ombudsman Leo Donnelly, and Senior Business Advisor Antonia Di Maio from the Office of the Ombudsmen for their comments and assistance regarding the factual accuracy of this article. However, all facts and opinions presented are the responsibility of the author. 
considers whether wide use of the name Ombudsmen should be allowed for private sector investigative and complaints bodies.

\section{RATIONALE FOR REVIEWING THE OMBUDSMEN LEGISLATION}

The Ombudsmen jurisdiction was introduced almost fifty years ago with the Parliamentary Commissioner (Ombudsman) Act 1962, precursor to the current Ombudsmen Act 1975 (the Act). The role has evolved since that time, with Ombudsmen playing a major role under the Official Information Act 1982 (OIA), the Local Government Official Information and Meeting Act 1987 (LGOIMA), the Crimes of Torture Act 1989 (COTA) and the Protected Disclosures Act 2000 (PDA). ${ }^{1}$

The Ombudsmen's role in redefining the constitutional relationship between the public service and the public of New Zealand is as important as ever given the growing reach of government into every aspect of citizens' lives. However, the constitutional framework in which the Ombudsman operates has changed significantly since the Office's establishment, with the creation of numerous complaints bodies, other officers of Parliament and other agencies which exact government accountability and handle citizens' complaints, like the Human Rights Commission, ${ }^{2}$ the Privacy Commissioner, the Independent Police Conduct Authority, the Health and Disability Commissioner, ${ }^{3}$ and the Inspector-General of Intelligence and Security.

The expansion of judicial review and appeal rights, and the creation of appeal bodies like the Social Security Appeal Authority, ${ }^{4}$ and the Immigration and Protection Tribunal, ${ }^{5}$ may also have resulted in some overlapping and parallel jurisdiction with the Ombudsman.

1 An overview of investigations undertaken by the Office of the Ombudsmen under each of these statutes, and the issues arising from these investigations, is contained in the Office's most recent annual report: Office of the Ombudsmen 2008/2009 Report of the Ombudsmen for the year ended 30 June 2009 (2009) at 22-32 [2008/2009 Report].

2 The protection of human rights provided by Ombudsmen in other countries is performed by the Human Rights Commission in New Zealand. See Linda C Reif "Reconciling Multiple Mandates: Ombudsman Institutions with a Human Rights Mandate" and Riitta-Leena Paunio "The Ombudsman as Human Rights Defender" (papers presented at the 9th World Conference of the International Ombudsman Institute, Stockholm, June 2009).

3 See Julia Maskill "The Ombudsmen and Health" (1982) 12 VUWLR 285 on the extent to which complaints about professional health decisions were within the Ombudsman's jurisdiction before the passage of the Health and Disability Commissioner Act 1994.

4 Social Security Act 1964, ss 12A-12R. See WGF Napier "The Ombudsmen and Social Welfare" (1982) 12 VUWLR 249 on the Ombudsman's jurisdiction over complaints about the Department of Social Welfare when a statutory right of appeal exists.

5 Immigration Act 2009, ss 217-251. 
These changes make it timely to review how well the Ombudsman jurisdiction is working. What is the unique role of the Ombudsman in New Zealand's Public Law Toolbox, and is it carrying out that role well? I define the Public Law Toolbox as including those instruments or levers, usually statutory, which provide a complaints function for those aggrieved by government action and which have powers of inquiry as independent watchdogs; and/or exact accountability and facilitate transparency in the government's performance and expenditure of public monies. The tools generally operate in the executive and parliamentary branches rather than the judicial branch of government, so they are additional to appeals and judicial review.

A whole article could be written on the effectiveness of the various mechanisms within the Public Law Toolbox, including the Ombudsmen, the Auditor-General, the Privacy Commissioner, the Independent Police Conduct Authority, the Health and Disability Commissioner, the Human Rights Commission, and the Children's Commissioner. ${ }^{6}$ Does the Ombudsmen's jurisdiction need to grow, shrink or change given the other public law tools described above?

Focussing just on Ombudsmen, however, is the Act effective in making government and its officials respond quickly, with compassion, meaningfully and effectively? ${ }^{7}$ As a constitutional watchdog, are Ombudsmen operating to their full potential ${ }^{8}$ Does the Act need amending or does it just need better implementation by the Ombudsmen's Office - or both?

This article's focus is the Ombudsmen Act, as opposed to the OIA and the LGOIMA, except to the extent that breaches of the OIA and the LGOIMA are problems with a matter of administration.

6 See M Chen Public Law Toolbox (LexisNexis, Wellington, forthcoming). That said, the Ombudsmen appear to be working effectively and efficiently with other agencies. There are already provisions in the Ombudsmen Act 1975 [the Act] that allow the Ombudsman to consult with the Privacy Commissioner (s 21A), the Health and Disability Commissioner (s 21B), and the Inspector-General of Intelligence (s 21C). Section 14 of the Act also requires an Ombudsman to forward complaints regarding police to the Independent Police Conduct Commission, and the Ombudsman can hear or obtain information from such persons (from other agencies) as they think fit and make such inquiries as they see fit. Section 17 also allows Ombudsmen to exercise their discretion not to investigate if there is an adequate alternative remedy or a right of appeal. So if another agency is already carrying out investigations which will remedy the complaint, or there is a right of appeal which it is reasonable for the complainant to use in the circumstances, then the Ombudsmen can decide to stop investigating. The Ombudsmen also consult informally with other government agencies like the New Zealand Police and the Children's Commissioner, as well as government departments such as the Ministry of Education, where they consider it necessary or desirable to do so - see Office of the Ombudsmen 2008/2009 Report, above n 1, at 15.

7 Bryan Gilling Ombudsman in New Zealand (Dunmore Press, Palmerston North, 1998) at 145.

8 Mary Seneviratne Ombudsmen: Public Services and Administrative Justice (Butterworths, London, 2002) at 324 where the Parliamentary Ombudsman Sir Michael Buckley raised concerns that the Ombudsmen have not reached their full potential. 
Both the Act and the OIA are rightly described as having constitutional significance, ${ }^{9}$ but the role the Ombudsmen perform under each statute is different. There has been some assessment of how the OIA and LGOIMA are operating, but relatively little review of the Ombudsmen's performance under the Act.

The Law Commission announced a review on 9 December 2009 of the OIA and Parts 1-6 of LGOIMA relating to official information, ${ }^{10}$ and released a Discussion Paper entitled "The Public's Right to Know" on 29 September 2010. That review refers to the Ombudsman Act, but only in the context of reviewing the OIA and LGOIMA. For example, the Discussion Paper notes that in some circumstances it may be more appropriate for a complainant to use the Ombudsmen Act's complaints procedures to complain about an agency's handling of an OIA request, than to use the complaints procedures under the OIA or LGOIMA. The Commission recommends extensive changes to both the OIA and LGOIMA, but does not recommend any changes to the Ombudsmen Act.

It is also instructive to consider the Public Audit Act 2001 (PA Act), which creates the office of the Controller and Auditor-General (Auditor-General). Like the Ombudsmen, the Auditor-General is an Officer of Parliament. The PA Act is less than ten years old, and provides useful guidance for any wholesale revision of the Ombudsmen Act.

For example, the requirement in Sch 3 of the PA Act that the Auditor-General must be appointed for a single term of seven years, the much larger fines provided at s 39 for offences against the PA Act compared with the Ombudsmen Act, and the requirement in s 36 for the AuditorGeneral to prepare a "work programme" and present it to Parliament, to outline the issues deemed important by the Auditor-General and the focus for the following 12 month period.

\section{IMPORTANCE AND EFFECTIVENESS OF OMBUDSMEN'S CONSTITUTIONAL ROLE}

One of the key lessons I have learned since moving 17 years ago from being a public law academic to a public law practitioner is the importance of Ombudsmen. I now understand the reality of the power imbalance between the government and those it governs, and how crucial it is to have Ombudsmen as a constitutional watchdog. They provide redress for individual grievances as well as improving standards of administration in government, ${ }^{11}$ they "humanise state administration" 12 by

9 See The Wyatt Co (NZ) Ltd v Queenstown-Lakes District Council [1991] 2 NZLR 180 (HC) at 190, citing Cooke P in Commissioner of Police v The Ombudsman [1988] 1 NZLR 385 (CA) at 391 who regarded the Official Information Act 1982 [OIA] as a constitutional Act.

10 Law Commission "Have Your Say about Access to Official Information" (press release, 9 December 2009).

11 Seneviratne, above $\mathrm{n} 8$, at 17.

12 Ann Abraham "The Future in International Perspective: The Ombudsman as Agent of Rights, Justice and Democracy" (2008) 61 Parliamentary Affairs 681 at 681. See also Brian Elwood "The Ombudsman Travels 
"supervising the administrative activities of the executive", ${ }^{13}$ they enhance government accountability to the public, ${ }^{14}$ thereby strengthening the bond of trust between the citizen and the state, ${ }^{15}$ and they provide a safety net when something goes wrong in public administration. As Bryan Gilling says: "Ombudsmen represent the possibility for ordinary people to bring to account the leviathan of the modern state."16

In 1999, the Ombudsman's constitutional role was defined by former Ombudsman and current Governor-General, Hon Sir Anand Satyanand, as a way: ${ }^{17}$

... to afford the ordinary citizen some kind of hearing and redress in a simple inexpensive and direct fashion when allegedly dealt with adversely by the actions of a large and remote government bureaucracy. The traditional means of redress - citizens being able to raise matters in Parliament through the local Member of Parliament, or to obtain judgment through the courts or to energise the Press had all proved to be less feasible than when originally envisaged. ... The larger problem was however expressed in the following way by Professor Donald Rowat in a 1962 article called 'An Ombudsman's Scheme for Canada' which, although expressing the Canadian viewpoint, registers likewise in this country:

It is quite possible nowadays for a citizen's right to be accidentally crushed by the vast juggernaut of the government's administrative machine. In this age of a welfare state, thousands of administrative decisions are made each year by the governments or their agencies, many of them by lowly officials; and if some of these decisions are arbitrary or unjustified, there is no way for the ordinary citizen to gain redress.

Sir Anand Satyanand also said this year that "good governance is a basic requirement for the enjoyment of all civil rights". ${ }^{18}$ In 2009, the current Chief Ombudsman, Beverley Wakem, said: ${ }^{19}$

to the Anglo-Saxon World" (paper presented to the 9thWorld Conference of the International Ombudsman Institute, Stockholm, June 2009) at 6, where the author talks about the adoption of Ombudsmen as part of a significant constitutional shift which has taken place over centuries and in different ways from the absolute power of monarchs to the electoral power of individuals.

13 Linda C Reif The Ombudsman, Good Governance and the International Human Rights System (Martinus Nijhoff, Leiden, 2004) at 1.

14 Ibid, at 2 .

15 Richard Kirkham, B Thompson and T Buck "Putting the Ombudsman into Constitutional Context" (2009) Parliamentary Affairs 600 at 602.

16 Gilling, above $\mathrm{n} 7$, at 21.

17 Anand Satyanand "The Ombudsman Concept and Human Rights Protection" (1999) 29 VUWLR 19 at 20.

18 Anand Satyanand "Speech to the Australian and New Zealand Ombudsman Association Conference" (Wellington, 6 May 2010) at 3.

19 Office of the Ombudsmen 2008/2009 Report, above n 1, at 6. 
... the role is clearly one of addressing citizens' complaints about public sector administration, and looking more widely at systemic issues which militate against good administrative practice. It is also one of promoting transparency and ensuring that citizens have adequate access to information. This allows citizens to participate more effectively in the democratic process, and encourages government agencies to be proactive in making information available which will assist citizens to do just that.

The reason why the Ombudsmen's constitutional role is so important is that the government usually has superior access to the information relevant to resolve any disputes or disagreements that arise - certainly better access than the citizen, business or organisation has. The government may also enjoy discretion as to whether or not it will share that information, subject to the OIA.

It is also hard to get leverage against a public law decision-maker who may not have acted fairly or reasonably, but who can always decide against the citizen, business or organisation. Ongoing relationships have to be factored in, especially where the government official or agency concerned funds or otherwise makes decisions affecting that citizen, business or organisation. Citizens, businesses or organisations understandably fear a pyrrhic victory as much as they fear a defeat.

While litigation continues to become less affordable for the majority of New Zealanders, the government always has deep pockets. It has taxpayer-funded resources in the form of in-house legal advisors and Crown Law, with appropriations for litigation funding being a standard feature of departmental and Crown Entity budgets. Moreover, even if a citizen wins, the government can and often does appeal, citing the public interest as its motivation. Further, judicial review remedies are limited to declarations or quashed decisions, with no monetary compensation.

Alternatively, Parliament can change the law, again citing the broader public interest. Parliament remains sovereign in law-making and even legislation inconsistent with any rights and freedoms in the New Zealand Bill of Rights Act 1990 prevails under s 4 of that Act.

Finally, courts are understandably deferential in reviewing decisions of government agencies and statutory bodies that have specialist expertise in particular areas, making it difficult to successfully challenge the actions of such bodies as unlawful, unfair and unreasonable. As the High Court said of Pharmaceutical Management Agency Ltd (a Crown Entity created by s 46 of the New Zealand Public Health and Disability Act 2000) in Roussel Uclaf Australia Pty Ltd v Pharmaceutical Management Agency Ltd: ${ }^{20}$

Nevertheless I accept that the nature of the decision and of the decisionmakers considered in the context, are relevant factors in determining the approach of the Court to the issues raised by the proceedings.

They justify a restraint which recognises the fact that such decisions are best made by those whose expertise fits them to make such decisions.

20 Roussel Uclaf Australia Pty Ltd v Pharmaceutical Management Agency Ltd HC Wellington CP9/96, 13 August 1997 at 17; aff'd [1998] NZAR 58; aff'd [2001] NZAR 476 (PC). 


\section{THE EFFECTIVENESS OF OMBUDSMEN VERSUS THE COURTS}

The difficulties of court proceedings against the government and the different nature of the Ombudsmen's jurisdiction mean that Ombudsmen are a more effective tool for challenging maladministration in some circumstances. The Canadian Supreme Court has said that: ${ }^{21}$

... the powers granted to the Ombudsman allow him to address administrative problems that the courts,

the legislature and the executive cannot effectively resolve.

Sir Kenneth Keith has undertaken analysis that suggests the "greater effectiveness of the Ombudsmen compared with the courts". ${ }^{22}$ Sir Kenneth reviewed the Ombudsmen's consideration of immigration cases concerning non-citizens and contrasted the courts' handling of the same cases. For example, in a case concerning the revocation by the Minister of a young Samoan's temporary permit, the Ombudsman undertook his own inquiries into matters set out in the Department's report to the Minister. He concluded that some of the statements were open to question and that the applicant's conduct had changed for the better. The Ombudsman persuaded the relevant department to recommend that the Minister extend the temporary permit on a trial basis. The Minister in fact cancelled the revocation order, restoring the currency of a temporary permit. ${ }^{23}$

Sir Kenneth also noted the ability of the Ombudsman to address a general (systemic) issue on the basis of the accumulation of experience, something a court can do only rarely. ${ }^{24}$ Sir Kenneth then said: ${ }^{25}$

... I wonder about just how well known the advantages of the [Ombudsmen's] Office are. ... I wonder in particular about the extent of lawyers' knowledge and teaching in the law schools. The importance of the Office is not, I think, reflected in the balance of New Zealand scholarship.

Kirkham, Thompson and Buck argue that "good administration" has a wider meaning than those principles that are subject of judicial review proceedings: ${ }^{26}$

It can be claimed of the rules of law that "fair processes, rational discourse and being called to account

for public behaviour are of its essence" because those values represent our constitutional expectations of

21 BC Development Corp v Friedmann [1984] 2 SCR 447 at 461.

22 Kenneth J Keith "Development of the Role of Ombudsman with Reference to the Pacific" (paper presented at the 22nd Australasian and Pacific Ombudsman Regional Conference, Wellington, February 2005) at 5.

23 Ibid.

24 Ibid, at 6

25 Ibid, at 7.

26 Kirkham, Thompson and Buck, above n 15, at 605-606. 
government. The challenge for public lawyers is that not all of these 'rule of law' values can be neatly encapsulated in purely legal doctrine.

$\cdots$

If the enforcement of standards of good administration is to be taken seriously it must occupy a shared territory between the courts and other institutions, such as the ombudsman.

For a complainant with no money to instruct a lawyer and little or no leverage with the public official concerned, getting the Ombudsmen to investigate means that the issue is immediately escalated to the Chief Executive of the public body, who must be notified of an investigation under s 18(1) of the Act.

The Ombudsmen's investigative (as opposed to adjudicative) role means the complainant is not required to put together the case against the public body. They can simply respond to the Ombudsman's questions aimed at determining whether the complaint is valid and requires redress.

At the very least, the complainant gets to have the complaint investigated by an independent officer of Parliament of some standing. At the most, if the Ombudsmen find substance to the complaint, they will get leverage to drive the government department or public organisation to the bargaining table, and may even get substantive redress, including compensation, as well as systemic process changes, thereby preventing the problem happening again. As Kirkham, Thompson and Buck suggest, making determinations on good administration involves a critical examination of the conduct of the officials involved, which is possible under the Ombudsmen's investigative jurisdiction, but something that is ordinarily avoided in judicial review proceedings. ${ }^{27}$

Section 22(3) shows how broad the Ombudsman's remedial recommendations can be:

If in any case to which this section applies an Ombudsman is of opinion-

(a) That the matter should be referred to the appropriate authority for further consideration; or

(b) That the omission should be rectified; or

(c) That the decision should be cancelled or varied; or

(d) That any practice on which the decision, recommendation, act, or omission was based should be altered; or

(e) That any law on which the decision, recommendation, act, or omission was based should be reconsidered; or

(f) That reasons should have been given for the decision; or

(g) That any other steps should be taken-

the Ombudsman shall report his opinion, and his reasons therefore, to the appropriate Department or organisation, and may make such recommendations as he thinks fit. ...

27 Ibid, at 607. 
The Ombudsmen also has value for the Government and its officials as a place to send complainants to get an independent investigation. A decision by the Ombudsman not to pursue an investigation may be the only way to convince complainants there is no merit to their complaint.

However, measuring the effectiveness of Ombudsmen in performing their constitutional role is difficult, as their impact in preventing grievances and resolving disputes more quickly and better than other avenues may be diffuse and intangible. ${ }^{28}$ The Ombudsmen's Office is currently reviewing its own achievement of "enhanced public trust and confidence in fair, responsive and accountable Government", which it measures by considering the following factors: ${ }^{29}$

(a) Improved administrative and decision-making practices in state sector agencies;

(b) Increased transparency, accountability and public participation in Government decisionmaking;

(c) Serious wrongdoing brought to light and investigated;

(d) People in detention treated humanely;

(e) Improved state sector capability and administrative, decision-making and complainthandling processes and knowledge of official information legislation; and

(f) Improved public awareness and access to Ombudsmen services.

\section{IS THE OMBUDSMEN'S RECOMMENDATORY JURISDICTION ADEQUATE?}

The intangible nature of these factors leads to the question of whether Ombudsmen would be more effective in addressing administrative grievances if they had the power to compel compliance with their recommendations under the Act. Ombudsmen do not make many recommendations and do not even appear to use their formal investigatory powers very often.

The recommendatory jurisdiction of the Ombudsmen under the Act means that they are reliant on persuasion. This is sometimes at odds with their powers to make binding recommendations under the OIA on disclosure of official information, unless vetoed by an Order in Council approved by the whole Cabinet within 21 days. This creates friction with departments and organisations which makes it harder for the Ombudsmen to be persuasive with the same bodies. Remember that the

28 See Beverley Wakem "Improving Operational Efficiency and Effectiveness" (paper presented to ANZOA Conference, Wellington, May 2010) at 7-9.

29 The Chief Ombudsman explained that the goal of undertaking this measurement is to ensure that the Ombudsmen's office is more on the front foot, quicker to respond, more relevant, and that the transaction costs for agencies in dealing with requests and in responding to the Office is reduced. Interview with Beverley Wakem, Chief Ombudsman, and officials from the Office of the Ombudsmen (Mai Chen, 3 March 2010). See also Frank Fowlie "A Practitioner's Guide to Evaluating Ombudsman Offices" (2007) ICANN Ombudsman <www.icann.org>. 
traditional role of the Ombudsmen under the Act generally concerns private citizens, whereas OIA cases often concern journalists, pressure groups and the political Opposition to the Government. ${ }^{30}$

If Ombudsmen have to resort to coercive powers too often, their power to persuade may be eroded. ${ }^{31}$ As Gilling says: "Forcing unpalatable decisions on politicians could lead to a strong government overturning the Office's recommendations or drawing its teeth." ${ }^{12}$ It is a difficult balancing act, which often leaves the Ombudsmen engaged in essentially negotiated forms of justice. ${ }^{33}$ That is why statistics on use of powers to compel and the number of formal recommendations are difficult to interpret even if they were more readily available. The reason is that because so much of the Ombudsmen's work is in private the lack of formal use of statutory powers may be the best testament to their effectiveness in using persuasion to get those complained about to redress the problem.

There are a large number of ways that Ombudsmen can make officials' lives very difficult under the Act. Section 19(2) of the Act gives Ombudsmen the power to summon and examine on oath any person. The Ombudsmen also have the power to enter and inspect the premises of any department or organisation, after first warning its Chief Executive, to carry out any investigation under s 27 of the Act. Use of these powers can be very resource-intensive, and Ombudsmen try to get the necessary information through informal means, making the use of such powers rare, even where the circumstances suggest that they would be of assistance.

There are, however, examples of the Ombudsmen formally using statutory powers. The "lying in unison" controversy, for example, concerned an OIA request relating to Algerian refugee Mr Ahmed Zaoui. ${ }^{34}$ Ombudsman Mel Smith became aware that relevant information he had requested to properly determine the complaint concerning the OIA request had not been supplied to him, by the leak of this media log: ${ }^{35}$

I was let down badly ... Everyone had agreed to lie in unison, but all the others caved in and I was the only one left singing the original song.

30 Robert Hazell "Freedom of Information: The Implications for the Ombudsman" (1995) 73 Public Administration 263 at 268.

31 Keith, above n 22, at 8 .

32 Gilling, above $\mathrm{n}$, at 107

33 See Ann Abraham "The Ombudsman as Part of the UK Constitution: A Contested Role?" (2008) 61 Parliamentary Affairs 206 at 210.

34 Office of the Ombudsmen Report of the Ombudsman, Mel Smith, Upon the Actions of the Department of Labour in regard to the Official Information Act Complaint by Sarah Boyle of the Office of the Leader of the Opposition (2004).

35 Ibid, at 4. 
The Ombudsman then decided under s 13(3) to undertake an own motion investigation given that the failure to provide the official information had affected his investigation under the OIA and had affected the complainant personally. Several officials were examined under oath, the Ombudsman concluding that the Department's omitting to provide him with information "contrary to law" and "was wrong" within the meaning of s 22(1) of the Act. He also expressed adverse opinions on the credibility of some officials and the way they fulfilled their departmental responsibilities: $:^{36}$

It has grieved me to do so, and I would hope that it will never again become necessary for me to express any similar opinions in the course of any future investigation which may fall to me.

He then referred to the Ombudsman's statutory powers under ss 19 and 27 and said: ${ }^{37}$

These are significant powers, and historically there has been little use of them. In this case, of course, I did find it appropriate to examine certain persons on oath and consider that to have been a proper and necessary action. I would regard it as highly unfortunate if the climate of compliance with the Official Information Act deteriorated to the point where it became normal practice for the full powers of the Ombudsmen under the Ombudsmen Act to be exercised.

These statements reflect the cooperation the Ombudsmen usually get for their investigations. ${ }^{38}$

The Ombudsmen have also used their powers under s 18(6) to refer substantial evidence of any significant breach of duty or misconduct to the appropriate authority. For example, in an own motion investigation into prisoner transport in 2007, the Ombudsmen considered that Chubb's noncompliance with ss $70 \mathrm{~B}$ and $70 \mathrm{C}$ of the Transport Act concerning driver hours was a significant breach of duty or misconduct and referred the matter to Land Transport New Zealand. ${ }^{39}$

The Act also gives Ombudsmen the power to encourage compliance with their recommendations, through indirect means. Under s 22(3), the Ombudsman can make recommendations and require a department or organisation to report within a specified time what steps they intend to take to implement the recommendation. The Ombudsman must send a copy of his or her report and recommendations to the relevant Minister. Under s 22(4), the Ombudsman can escalate the matter further if he or she thinks no adequate response is being made, by sending his or her report and recommendations to the Prime Minister and to Parliament. Ombudsmen have sent one such report to Parliament. Five further reports have been made under s 29 of the Act, which is

36 Ibid, at 46.

37 Ibid.

38 As Larry Hill concluded in a very old study of complaints reported in the 1973 Annual Report of the Ombudsman, "bureaucrats have not obstructed the Ombudsman ... cooperation is the norm." Larry B Hill "Institutionalisation, the Ombudsman, and the Bureaucracy" (1974) 68 Am Pol Sci Rev 1075 at 1084-1085.

39 Office of the Ombudsman Report of the Ombudsmen for the year ended 30 June 2007, at 18. 
the requirement to report annually "without limiting the right of an Ombudsman to report at any other time".

The Standing Orders of the New Zealand House of Representatives were amended in 2008 to provide in Standing Order 387 that reports from Officers of Parliament, like the Ombudsmen, other than an annual report, will stand referred to the relevant subject committee for examination, given the infrequent scrutiny of such reports up to that time.

The Report of the Standing Orders Committee said that: ${ }^{40}$

A committee to which a report stands referred under this new provision should consider requesting a
briefing from the Officer of Parliament and, if applicable, from Government officials or spokespeople
from a local authority ... [T] he Ombudsmen do have the power to request a response [Ombudsman Act
1975, s 22(3)]. The involvement of a select committee may promote efforts to engage in implementing
or responding to recommendations. The select committee may itself make recommendations in the light
of the report, and recommendations addressed to the Government would require a response [under
Standing Order 253].

The Ombudsmen can also require, under s 23 of the Act, local authorities and organisations named under Part 3 of sch 1 to publish a summary of the report and recommendations and make it available for inspection and copying by members of the public. A public notice that the report and recommendations are available for public inspection shall be put in whatever media the Ombudsman requires. This provision appears to have been used on only one occasion, against a city council which granted permission to erect a block wall on the boundary in contravention of town planning ordinances, and after telling the complainant that a wall could not be erected without his consent. ${ }^{41}$

Under s 24, the Ombudsman can also inform the complainant of his or her recommendation with whatever comments and at such time as he or she thinks fit, if there is no appropriate or adequate action by the department or organisation within a reasonable time.

The threat of these "sunlight is the best disinfectant"42 mechanisms should not be underestimated. And the judiciary have supported a broad view of the Ombudsmen's jurisdiction, unlike in other countries where repeated judicial challenges to the Ombudsmen's jurisdiction have severely

40 Standing Orders Committee Review of Standing Orders, Report of the Standing Orders Committee (I.18B, 48th Parliament, August 2008) at 42.

41 Office of the Ombudsmen 10th Compendium of Case Notes of the Ombudsmen (1992) Case note A2618 at 76-78. The Ombudsman, Nadja Tollemache, recommended that $\$ 4000$ be paid in compensation for the loss of the rights to be notified and heard, but the City Council's CEO decided to pay only half of that amount in compensation. The Ombudsman then required a summary of the case to be publicly notified under s 23 , given that the recommendation had not been completely implemented, and because the matter of discretion to dispense with consent is a matter of some interest to members of the public.

42 Louis Brandeis Other People's Money and How the Bankers Use It (FA Stokes, New York, 1914) at 92. 
hampered activities on behalf of the complainant. ${ }^{43}$ In the leading case of The Wyatt Co (NZ) Ltd v Queenstown-Lakes District Council, Jeffries J said: ${ }^{44}$

The allegations of errors, unreasonableness and failure to take into account relevant matters are attacks on the several judgments the Chief Ombudsman had to make in the functions ordained for him by the Act. That Act requires him to exercise his judgment using experience and accumulated knowledge which are his by virtue of the office he holds. Parliament delegated to the Chief Ombudsman tasks, which at times are complex and even agonising, with no expectation that the Courts would sit on his shoulder about those judgments which are essentially balancing exercises involving competing interests. The Courts will only intervene when the Chief Ombudsman is plainly and demonstrably wrong, and not because he preferred one side against another.

In the United Kingdom, there have been recent judicial challenges to the ability of a Government Minister to reject an Ombudsman's recommendation. ${ }^{45}$ The Court of Appeal in $R$ (Bradley) v Secretary of State for Work (Bradley) decided that Ministers are bound by the Ombudsman's findings of fact in investigations unless they are shown to be flawed or irrational, or there is genuine fresh evidence to be considered. Wall LJ summed up the decision by stating: ${ }^{46}$

... it is not enough for a Minister who decides to reject the Ombudsman's finding of maladministration simply to assert that he had a choice; he must have a reason for rejecting a finding which the Ombudsman has made after an investigation under the powers conferred by the Act.

The High Court in Equitable Members Action Group considered the partial rejection of an Ombudsman's findings of maladministration and the recommendation of a compensation scheme. The Court cited Bradley, and said the following: ${ }^{47}$

43 Sir George Laking refers to the frustration of the first Victorian Ombudsman. See for example, Booth $v$ Dillon (No 1) [1976] VR 291 (SC); Booth v Dillon (No 2) [1976] VR 434 (SC); Booth v Dillon (No 3) [1977] VR 143 (SC); cited in George Laking "The Ombudsman in transition" (1987) 17 VUWLR 307 at 310. See also Kenneth J Keith "Judicial Control of the Ombudsmen?" (1982) 12 VUWLR 299.

44 The Wyatt Co (NZ) Ltd v Queenstown-Lakes District Council, above n 9, at 191. This case was not appealed to the Court of Appeal. It has been further considered in Rangitikei District Ratepayers Association Inc $v$ Rangitikei District Council HC Wanganui CP12/00, 28 September 2000 and was referred to in Sanford Ltd $v$ Minister of Fisheries HC Wellington CP257/94, 31 October 1994 and Television New Zealand $v$ Ombudsman [1992] 1 NZLR 106 (HC).

$45 R$ (Bradley) v Secretary of State for Work [2009] QB 114 (CA); R (Equitable Members Action Group) v HM Treasury [2009] EWHC 2495 (Admin), [2009] All ER (D) 163 (QB).

$46 R$ (Bradley) $v$ Secretary of State for Work, above $\mathrm{n}$ 45, at [51]. See Ann Abraham "The Ombudsman and the Executive: The Road to Accountability" (2008) 61 Parliamentary Affairs 535, for the Ombudsman's own view about the significance of what happened.

47 (Equitable Members Action Group) v HM Treasury, above n 45, at [66]. 
Although not bound by them, the public body can only reject the findings of the Ombudsman for "cogent" reasons, that is for reasons other than merely a preference for its own view. That is not a precise test, but it would be wrong in our view for us at this level to attempt a further definition of the "cogent" reasons test or to suppose that there is some exhaustive list of such reasons. What is required instead is a careful examination of the facts of the individual case - with the focus resting upon the decision to reject the findings of the Ombudsman, rather than the Ombudsman's findings themselves.

Particular factors weighing against rejection in the present case are the complex nature of the Ombudsman's investigation, together with the fact that her findings were made after taking detailed expert advice, including actuarial advice; and the fact that the public bodies involved in the Ombudsman's investigation had extensive opportunities to make representations. On the other hand, where it can be demonstrated that the Ombudsman has gone wrong in fact or in law, or where the Government has carried out further work not done by the Ombudsman, the case for rejection may be easier to justify.

I conclude that the Ombudsmen's record of making relatively few recommendations, and their enviable record of having the over-whelming majority of the recommendations they do make adopted, is not because of undue compromise or soft recommendations.

Although most of the thousands of complaints the Ombudsmen investigate each year are resolved by informal inquiry, where the outcome of an investigation is documented there are good examples of the Ombudsmen making helpful substantive recommendations which redress unfairness:

(a) In a case where the Ombudsman found the IRD omitted to clarify a student's loan position with her, the Ombudsman invited IRD to review the student's loan position, which they did. Although the IRD could not write off the loan (there was no proof it was paid), the IRD did cancel accumulated penalties and interest; ${ }^{48}$

(b) In a case where tenants renting a school house from the Board of Trustees found they were paying \$35 per week more than permitted under the Ministry of Education guidelines, the Ombudsman was initially satisfied that the Ministry would work with the Board to remedy the situation. When this did not happen within six months, the Ombudsman reopened the investigation and formally recommended the Ministry pay the tenants a sum equal to the rent paid in excess of the Ministry's guidelines. The Ministry eventually accepted the recommendation and fully compensated the tenants; ${ }^{49}$ and

48 Office of the Ombudsmen 14th Compendium of Case Notes of the Ombudsmen (2007) case note W46487 at 19.

49 Ibid, at 28 . 
(c) In the 2007 Painted Apple Moth report, the Ombudsman recommended amending s 7A of the Biosecurity Act 1993, which enables actions taken to eradicate organisms, including aerial spraying, under that Act to be exempted from the constraints imposed by Part 3 of the Resource Management Act 1991, including the requirement for resource consents. The Report stated: ${ }^{50}$

\begin{abstract}
Also, I consider that there needs to be consideration given to the desirability of the seemingly automatic use of section 7A of the Biosecurity Act, which has the effect of overriding protections which might otherwise exist under Part 3 of the Resource Management Act. I appreciate that the processes of that Act can be time consuming, but it should be possible to devise a procedure which provides a sufficient opportunity for the Environment Court to furnish an independent judgement. ...
\end{abstract}

\title{
Recommendation 2
}

I therefore recommend that amendments to the relevant legislation be considered and enacted as a matter of urgency so that they are immediately available should the need arise.

The current Chief Ombudsman has only had to make one formal recommendation since she took office three years ago because the moral suasion of the Office and the threat of using the powers available to her have been sufficient to resolve complaints. As Gilling writes: ${ }^{51}$

The Ombudsmen's strongest sanction was to make a recommendation. This was done relatively infrequently, since Powles [the first ombudsman] had decided that informal means of complaint resolution were preferable in terms of efficiency and relations. "Using praise as an encouragement, criticism as a punishment, and possible censure as a prophylactic have increased the Ombudsman's authority potential beyond the bare outlines of the Act, although the precise effect is incalculable."

Also, the alternative of giving the Ombudsmen binding decision-making powers is fraught. ${ }^{52} \mathrm{It}$ would change the role of Ombudsmen into a general administrative appeal tribunal, ${ }^{53}$ and create duplication with the court's judicial review role. We would lose the unique benefits of the Ombudsmen's flexibility which allows them to solve problems that no other public law tool can

50 Office of the Ombudsmen Report of the Opinion of Ombudsman Mel Smith on Complaints Arising from Aerial Spraying of the Biological Insecticide Foray $48 B$ on the Population of Part of Auckland and Hamilton to Destroy Incursions of Painted Apple Moths, and Asian Gypsy Moths, respectively during 2002 2004 (2007) at 11 (emphasis added).

51 Gilling, above n 7, at 63, citing Larry Hill "The New Zealand Ombudsman's Authority System" (1968) 20 Political Science 40 at 48.

52 Although note that countries like Sweden and Finland do give their Ombudsmen power to prosecute officials. See the binding powers of ombudsmen in other countries in Reif, above n 13, at 19.

53 As Reif said, ibid, at 18: "the institution would become just another type of court or tribunal - institutions which the state already has in place". 
resolve. Sir George Laking identified the Ombudsmen's "flexibility in the conduct of investigations and in recommending remedies calculated to achieve substantial justice as between the individual and the state" as one of the three essential features of the Office. ${ }^{54}$

Kirkham, Thompson and Buck argue that Ombudsmen's effectiveness in resolving the more difficult areas of good administration and governance is precisely because their findings are not binding: ${ }^{55}$

... were an attempt made to shackle the ombudsman's flexibility with legalistic procedural requirements,

then it is highly probable that the institution's effectiveness would be markedly reduced.

In contrast, Professor John McMillan, the Australian Commonwealth Ombudsman, has proposed that: ${ }^{56}$

It may be thought appropriate to extend this s 15 power [under the Ombudsman Act 1976 to recommend actions that should be taken by an agency to address deficient administrative action], to provide that an agency shall be taken to have the power to cancel or vary a decision if the Ombudsman has made a recommendation to that effect.

However, he acknowledges that requiring an agency to act on an Ombudsman recommendation to correct a decision that is otherwise final "may interfere with legislative certainty and allow a departure from Parliament's intention, in the same way as giving an officer an extra statutory concession power".

I doubt a majority of New Zealand Parliamentarians would ever agree to legislate to give the Ombudsmen binding powers over substantive law-making. As Sir George Laking wrote about the introduction of the Ombudsmen jurisdiction: ${ }^{57}$

The Bill, as presented to the House, was deceptively simple in its approach ... It gave the Ombudsman no power of decision, confining him to the right to make recommendations which might or might not be accepted by the government. It appeared to involve ministers in the Ombudsman process only to the

54 Laking, above $\mathrm{n} 43$, at 311 . Stephen Owen also said that "It may be that this inability to force change that represents the central strength of the office and not its weakness". S Owen "The Ombudsman: The Essential Elements and Common Challenges" in L Reif, M Marshall and C Ferris (eds) Ombudsman: Diversity and Development, (Edmonton International Ombudsman Institute, Alberta, 1992) at 52. See also Keith, above $n$ 22, at 2, where he cites Louis Marceau, the Quebec Public Prosecutor who stressed that "flexibility is essential."

55 Kirkham, Thompson and Buck, above n 15, at 608.

56 Commonwealth Ombudsman Mistakes and Unintended Consequences - a Safety Net approach (2009) at $15-16$.

57 Laking, above n 43, at 308 . 
extent of authorising and in some cases requiring the Ombudsman to consult with ministers before making a recommendation.

However, Parliament may be prepared to consider adding to our Act a provision similar to s 10 of the Australian Commonwealth Ombudsmen Act 1976, which allows an Ombudsman to grant a certificate to a complainant certifying that there has been unreasonable delay in deciding whether to do an "act or thing". A decision not to do the act or thing is deemed to have been made on the date on which the certificate is granted. This deemed decision is thereupon reviewable by the "prescribed tribunal". The section only applies where no time limit for the making of a decision is prescribed, and the decision is reviewable by a "prescribed tribunal", which includes the Administrative Appeals Tribunal. ${ }^{58}$

A s 10 certificate has never been issued because: ${ }^{59}$

The need for such a certificate is often obviated by the lodgement or threatened lodgement of an application for a certificate, which may impel decision makers to take immediate action.

Even if a certificate is issued, the person may still encounter filing fees and court costs in appealing the matter (depending on the nature of the "prescribed tribunal"), and they still are not guaranteed a favourable decision by the appeals tribunal. However, Professor MacMillan, says that he supports the Ombudsman having such a power "as an extra lever to force an agency to make a decision". ${ }^{60}$ The Ombudsman is not second-guessing the substantive decision of any person, but simply ensuring that a person actually carries out his or her public obligations. The Ombudsman's certificate that the person is deemed not to have done the act or thing on a particular date allows the complainant then to escalate that matter to the prescribed tribunal to get a decision made on their matter.

\section{ESSENTIAL AMENDMENTS}

There are a number of key areas in which the Act needs to be reformed, to ensure that it reflects recent developments, and to allow the Ombudsmen's Office to properly carry out its constitutional role.

58 A corresponding provision appears in s 25(5) of the Administrative Appeals Tribunal Act regarding cases where a time limit is prescribed.

59 See Administrative Review Council report to the Attorney-General on The Relationship between the Ombudsman and the Administrative Appeals Tribunal (1985) at 19.

60 Email from Professor MacMillan to Mai Chen regarding the use of s 10 powers under the Australian Commonwealth Ombudsman Act 1976 (27 May 2010). 


\section{A Public Ignorance of the Ombudsmen's Office}

I have encountered widespread ignorance of the Office in advising clients on using the Ombudsmen's office under the Act with the result that clients sometimes go to lawyers who bring failed judicial review proceedings when a complaint to an Ombudsman would have been cheaper and given a more effective remedy. ${ }^{61}$

The New Zealand Ombudsmen's public survey in 2008/2009 found that they needed to increase their efforts to be more accessible across different sectors of society, and to communicate their role and functions on a wide variety of fronts. ${ }^{62}$ That said, the Ombudsmen dealt with 8,855 complaints in the $2008 / 2009$ year, up from 7,257 complaints in the $2007 / 2008$ year, due mainly to the tough economic climate resulting in departments and public organisations reviewing staffing and service levels. It is difficult to compare numbers of complaints to the Ombudsman in 2009 with the Privacy Commissioner (806 complaints), ${ }^{63}$ the Health and Disability Commissioner (1,360 new complaints), ${ }^{64}$ and the Human Rights Commission (3,489 complaints, 1,405 of those raising issues of unlawful discrimination $)^{65}$ as these agencies can take complaints against private individuals and companies as well as the state sector and government relating to their particular statutory jurisdiction.

Although Ombudsmen do not have a publicity or an education function in the Act, the Office does run a Publicity and Public Awareness Programme. In addition to publishing their Annual Report, Practice Notes, information pamphlets and Compendium of Case Notes, the Ombudsmen's Office also run training programmes which are offered on request to those looking to increase their understanding of the role of the Ombudsmen. In 2008/2009, the Office conducted over 20 training sessions, delivered over 40 presentations on the role of the Ombudsmen, and operated regional clinics in Dunedin, Oamaru, Nelson and Blenheim. ${ }^{66}$

61 As Professor Seneviratne says, "lack of awareness about the existence and role of the ombudsman presents a major barrier to access. ... Surveys have revealed little awareness of the [UK] Parliamentary Ombudsman." Seneviratne, above n 8, at 146-147. The Ombudsmen's remit is still not well known or understood by citizens and their lawyers. See also Philip Giddings "The Parliamentary Ombudsman: A classical Watchdog" in Oonagh Gay and Barry K Winetrobe (eds) Parliament's Watchdogs: At the Crossroads (The Constitution Unit, University College of London, London, 2008) at 96.

62 Office of the Ombudsmen 2008/2009 Report, above n 1, at 38.

63 Privacy Commissioner Annual Report of the Privacy Commissioner 2009 (2009) at 5.

64 Health and Disability Commissioner Annual Report for the year ended 30 June 2009 (2009) at 3.

65 Human Rights Commission Annual Report 2009 (2009) at 30.

66 Office of the Ombudsmen 2008/2009 Report, above n 1, at 36. These presentations were delivered to media organisations, government ministers, local authorities, central government agencies, universities and private organisations were among those who received training, and presentations were delivered to professional 
The Ombudsmen's Office undertakes these activities because "[a]n improved understanding of the Ombudsmen's role and associated legislation is expected to contribute to better decision-making and to fewer complaints being lodged with government agencies and our office. "67 Improving public awareness was also identified as a key organisational priority in the 2008/2009 Report of the Ombudsmen for the year ended 30 June 2009 (2008/2009 report). ${ }^{68}$ The Ombudsmen's Office is also more proactively publishing what they do to guide complainants, their lawyers if any, and the agencies. ${ }^{69}$

In addition to public ignorance, it appears that Ombudsmen are infrequently used by Parliament itself, despite being officers of Parliament. Any Committee of Parliament may at any time refer to an Ombudsman for investigation and report back to the Committee any petition that is before the Committee and the Ombudsman can investigate the matter as far as they are within his jurisdiction under s 13(4) of the Act. However, there only appears to have been one Parliamentary petition referred to the Ombudsman by a Select Committee under s 13(4) in the last 10 years. $^{70}$

This may be because MPs want to hear and decide the appropriate response to petitions themselves, in the first instance, with referral to an Ombudsman only seen as a last resort. Further, petitions often raise issues of policy rather than issues that require an investigation into the facts of the case. However, it may also be due to MPs' ignorance of s 13(4) of the Act, and the particular skills that Ombudsmen can bring to such investigations.

Ombudsmen are understandably concerned about being accused of "touting for business" or stirring up complaints. Certainly when the Ombudsmen's Office was first established, there was sensitivity that Ombudsmen not engage in "improper solicitation of business",71 and politicians

development conferences, government agencies, local authorities, Crown entities, tertiary education institutions, and non government organisations.

67 Office of the Ombudsmen "Training and speaking engagements" <www.ombudsmen.govt.nz>.

68 Office of the Ombudsmen 2008/2009 Report, above n 1, at 37. Significant efforts on the part of the Ombudsmen to educate the public about the Office and the Act have always been made. See Gilling, above n 7 , at 120 .

69 The Ombudsmen Rules 1989 enable the Ombudsmen to publish reports relating generally to the Ombudsmen's functions under the Act, the OIA or the LGOIMA.

70 The Commerce Select Committee referred the petition of John Dickson to the former Chief Ombudsman, John Belgrave, in 2007: Office of the Ombudsmen, 2008/2009 Report, above n 1, at 20.

After Mr Belgrave's death in December 2007, the petition had to be referred once more in 2008 to the new Ombudsman, David McGee. Prior to this, in 1978, the petition of GW Hawkins and 5088 others was referred, and the Ombudsman in reporting expressly refrained from investigating the actions of the Ministers involved. In 1979 the petition of Rangitahi Access Group, which had arisen out of an earlier Ombudsman inquiry, was referred, effectively for the Ombudsman to complete that inquiry. Correspondence between the Office of the Ombudsmen and Mai Chen (21 April 2010)

71 Gilling, above n 7, at 44. 
were reluctant to have Ombudsmen "encouraging" complaints against their departments and public organisations. ${ }^{72}$ That may explain why the Ombudsmen legislation did not include an express statutory function to educate the public about the Act and the Ombudsmen's role.

Other independent agencies, like the Securities Commission, have an express function to "promote public understanding of the law and practice relating to securities and the law and practice relating to financial advisers". ${ }^{73}$ The Privacy Commissioner has an express function to "promote, by education and publicity, an understanding and acceptance of the information privacy principles and of the objects of those principles"74 and the Human Rights Commission has various functions relating to promotion and education. ${ }^{75}$

\section{Recommended amendment}

Section 13 of the Act should be amended to include the following additional function:

To promote, by education and publicity, an understanding of the Ombudsmen's role, the Act, and good

administration.

An express statutory function to educate the public about the Act and the Ombudsmen's role, together with increased resourcing to carry out this function, would ensure that the Ombudsmen can legitimately perform such essential activities with proper funding instead of trying to cram education and promotion into the edges of a very busy role, using what resources can be spared from the prescribed output class. It would allow the Office to hire dedicated staff and give these functions the time they deserve.

The Ombudsmen could also fund publications like the UK Parliamentary and Health Service Ombudsman "Principles of Good Administration", ${ }^{76}$ to prospectively promote good administration rather than the retrospective eradication of administrative problems. ${ }^{77}$

Finally, this education and publicity function would allow the Ombudsmen to publicise its role under the PDA and the COTA. The Protected Disclosures Amendment Act 2009, which came into force on 27 June 2009, enhances the Ombudsmen's role of assisting whistle-blowers and to give

72 Ibid.

73 Securities Act 1978, s 10(1)(d).

74 Privacy Act 1993, s 13(1)(a).

75 See Human Rights Act 1993, ss 2(a)-(d) and 5(1)(a).

76 The six principles are: getting it right; being customer focused; being open and accountable; acting fairly and proportionately; putting things right and seeking continuous improvement.

77 See Abraham, above n 33, at 209. 
information and guidance to public or private sector employees on using the Act. However, the Ombudsmen only reported eight enquiries in the 2008/2009 Report. ${ }^{78}$

In contrast, the 2008/2009 Report highlights a number of significant concerns arising from the Ombudsmen's role under the COTA, regarding potential cruel and inhumane treatment in mental health, faulty legal paperwork in mental health, and unlawful detention in prisons where detention in a hospital was required under the Criminal Procedure (Criminal Impaired Persons) Act 2003. ${ }^{79}$ Although the Ombudsmen, as a National Preventive Mechanism under COTA, must provide at least one report each year to the House of Representatives on the exercise of their functions under COTA, the legislation does not include a specific publicity and education function. Expanding the Ombudsmen's functions in this respect would allow the Ombudsmen to create greater awareness of the requirements of the Optional Protocol to the Convention against Torture and other Cruel, Inhumane or Degrading Treatment or Punishment, and the relevant domestic legislation concerning the detention of people against their will. ${ }^{80}$

\section{B Delay in Resolving Complaints}

Overall, the Ombudsmen's Office has been efficient in resolving disputes, mainly within six months despite its very heavy workload, but have experienced much longer delays of well over a year to resolve complaints where the department or organisation was slow to respond to the Ombudsman's requests for information about the complaint. That said, this timeframe is still much faster than trying to resolve the issue in court.

The Office of the Ombudsmen's 2008/2009 Report shows that: ${ }^{81}$

(a) 94 per cent of general complaints under the Ombudsmen Act were completed within six months. On average, complaints took 59 days to investigate;

(b) 100 per cent of prisoner complaints under the Ombudsmen Act were completed within six months. On average, complaints took seven days to investigate;

(c) 76 per cent of Official Information Act complaints were completed within six months. On average, complaints took 97 days to investigate; and

78 Office of the Ombudsmen 2008/2009 Report, above n 1, at 29.

79 Ibid, at 30-32.

80 Mental Health (Compulsory Assessment and Treatment) Act 1992; Intellectual (Compulsory Care and Rehabilitation) Act 2003; Criminal Procedure (Mentally Impaired Persons) Act 2003; Alcoholism and Drug Addiction Act 1985; Corrections Act 2004; Criminal Justice Act 1985; Extradition Act 1999; Summary Proceedings Act 1957; Terrorism Suppression Act 2002; Immigration Act 1987; Protection of Personal and Property Rights Act 1988.

81 Office of the Ombudsmen 2008/2009 Report, above n 1, at 59-60. 
(d) 89 per cent of Local Government Official Information and Meetings Act complaints were completed within six months. On average complaints took 61 days to investigate.

A comparison with the Annual Reports of the Privacy Commissioner, Human Rights Commission and Health and Disability Commissioner shows that the Ombudsmen take a similar amount of time to other bodies to resolve complaints. ${ }^{82}$

The Ombudsmen's own survey of members of the public in 2008/2009 found that "although two-thirds of complainants are satisfied with our service, there is less satisfaction with the timeliness of our service". The Report goes on to say that: ${ }^{83}$

... we are taking steps to reorganise and refocus the use of resources, to address concerns that were raised in terms of timeliness issues. It is also important to remember that, to an extent, we are dependent on receiving timely responses from government agencies in order to progress an investigation in a timely manner.

Timeliness has improved with enhancements to the Office's case management system, which captures and records all complaints, requests and enquiries as soon as they are received. ${ }^{84}$ The enhanced system is also expected to help highlight systemic issues more effectively, to help manage workflow within the office, to measure where work pressure builds and what amount of work is required to achieve particular outcomes. ${ }^{85}$

The department or public organisation complained about needs to be given proper rights to respond consistent with natural justice, but some departments and public organisations are tardy or refuse to respond, to an Ombudsman's requests for a response to complaints. In one recent case, the organisation took five months to respond to the Ombudsman's "please explain" about the complaint. Meanwhile, the complainant, whose institution had lost public funding due to the organisation's alleged wrong decision, struggled to keep her business viable. Twelve months after the original complaint was made, the Ombudsman made a provisional opinion. After a further round of

82 During the 2008/2009 year the Privacy Commissioner received 806 new complaints and closed 822 complaints. 74 per cent of those complaints were closed within six months of receipt and 94 per cent within a year of receipt. Privacy Commissioner Annual Report of the Privacy Commissioner 2009 (2009) at 25 and 28. During the 2008/2009 year the Human Rights Commission received 1405 complaints which raised issues of unlawful discrimination (out of 5834 complaints and inquiries). The Human Rights Commission closed 1135 complaints. 74.4 per cent of complaints were closed within sixty days of receipt and 96 per cent were closed within twelve months of receipt. Human Rights Commission Annual Report 2009 (2009) at 30 and 31. During the 2008/2009 year the Health and Disability Commissioner received 1378 complaints. 87 per cent of those complaints were closed within six months of receipt, and 96 per cent were closed within a year. Health and Disability Commissioner Annual Report for the year ended 30 June 2009 (2009) at 46.

83 Office of the Ombudsmen 2008/2009 Report, above n 1, at 38.

84 Ibid, at 46.

85 Ibid, at 8 . 
comments by both parties, the public organisation was encouraged by the Ombudsman to meet with the complainant to see if the matter could be resolved, with the threat that failure to do so would result in a formal opinion being issued. The complaint was resolved, 15 months after it was filed, with a confidential settlement.

Undue delay by the department or the public organisation is itself a "matter of administration" which is unreasonable, unjust, oppressive and improperly discriminatory. It renders the complainant powerless, unless the Ombudsman is prepared to take the department or public organisation to task about the delay. I have had to request Ombudsmen to do that, but complainants who are not represented tend not to be so bold. Some clients have come to me after making a complaint themselves to the Ombudsmen's Office and not getting a response.

Gilling writes that timeliness of response has always been a problem. In 1986, Chief Ombudsman Castle named three unacceptably tardy departments - the Treasury, Inland Revenue and the Development Finance Corporation. In 1988, the Ombudsman resorted for only the second time ever to take a matter to the Prime Minister. This concerned a Customs delay of nearly three years in cooperating with an investigation, resulting in the Chief Ombudsman recommending an ex gratia payment to the complainant to cover his legal costs. When the Comptroller refused to pay, the Chief Ombudsman referred the matter to the Deputy Prime Minister who enforced the payment after his own review. ${ }^{86}$

These actions are ones of last resort for the Ombudsmen, and there has to be an easier mechanism to ensure that the department or organisation is taking the Ombudsman's requests for information seriously and responding promptly.

\section{Recommended amendment}

Just as s 29A of the OIA gives a deadline on providing the Ombudsman with any information or document or thing requested "as soon as reasonably practicable, and in any case not later than 20 working days after the day on which that requirement is received by that Department ... or organisation", so departments and organisations should have to respond to Ombudsman requests for information about a complaint under s 19(1) of the Ombudsmen Act within 20 working days.

The amendment should allow the Chief Executive of a department or organisation to request an extension, but this must be made within 10 working days of receiving the Ombudsman's information request, and only for good reason, which should be set out in the request along with the requested period of extension. Any extension should only be for a reasonable period of time having regard to

86 Gilling, above n 7, at 99. In contrast, an earlier study done of the complaints, processed and investigated as set out in the Ombudsmen's Report the Year ended 31 March 1973, found under "speed of departmental reply" that almost one-third of departments had substantively replied to the Ombudsman within a week of receiving a request for information. Nearly as many replied in the second week, and less than one-tenth took more than a month. See Hill, above n 38, at 1082. 
the circumstances. The amendment should require the Ombudsman to decide on the request as soon as reasonably practicable and to notify the department or organisation as well as the complainant of the decision.

\section{Inconsistent Application of Ombudsmen's Jurisdiction}

There is no presumption that the Ombudsmen and Official Information Acts will apply to any departments and organisations exercising public power affecting the public, and which are publicly funded. Rather, s 32 of the Ombudsmen Act enables the Governor-General by Order in Council to expressly add or remove from the list of departments or organisations which are subject to the Act's jurisdiction. There is no requirement to bring any changes to the attention of Parliament.

After almost 50 years of credibility-building and incremental increases in the scope of the Ombudsman's jurisdiction, ${ }^{87}$ with some carve-outs, ${ }^{88}$ a statutory presumption of coverage by the Ombudsmen and Official Information Acts should be created in the Act. As the Legislation Advisory Committee Guidelines on Process and Content of Legislation state: ${ }^{89}$

As a general principle, the Ombudsmen should have jurisdiction over departments and other agencies that make decisions that relate to matters of central or local government administration and which affect members of the public. The factors to be taken into account are the relationship between the agency and central or local government and its public purpose ... .

In general, the Ombudsmen Act 1975 and either the Official Information Act 1982 or the Local Government Official Information and Meetings Act 1987 should apply to a public agency. If it is proposed that a public agency not be subject to those Acts, the Office of the Ombudsmen should be consulted.

In the case of Crown entities, the Official Information and Ombudsmen Acts should apply to all newly established entities, and to entities with legislation under review. An exception is where the entity's functions are judicial in nature - such as where the members of the entity examine evidence on oath and

87 As early as 1965, American academic Walter Gelhorn, commented that the exclusion of any matter for which a judicial remedy could be sought, the restriction of the jurisdiction to matters of administration, and the exclusion of local authorities from the jurisdiction were potential areas for improvement in the 1962 Act. Walter Gellhorn "The Ombudsmen in New Zealand" (1965) Cal L Rev 1155 at 1155. See also Gilling, above n 7, at 51-53; Sir Guy Powles "The New Zealand Ombudsman - the early days" (1982) 12 VUWLR 207 at 211-213; Laking, above n 42, at 310, said that the Office had by then gained sufficient credibility in the eyes of the public and the government in its early years "to support an extension of its jurisdiction to education and hospital boards."

88 The creation of the Independent Police Conduct Authority to decide complaints about the police, for example, took away some of the Ombudsmen's jurisdiction. See Gilling, above n 7, at 100-101. See further Official Information Act 1982, s 49.

89 Legislation Advisory Committee Guidelines on Process and Content of Legislation (May 2001) at 186-187. 
make determinations affecting individual interests or rights on the basis of that evidence (eg the Police

Complaints Authority).

\section{Recommended amendment}

New Zealand should consider including a hybrid approach in the Act, comprising a presumption that some generic types of bodies will be covered, and requiring specific bodies which might have doubtful status or be difficult to easily fit into a generic description to be expressly added to a list by Order in Council. ${ }^{90}$

The Australian Ombudsmen Act 1976 does not set out a list of agencies to which the Act applies, but states in s 5(1)(a) that "the Ombudsman shall investigate action, being action that relates to a matter of administration, taken either before or after the commencement of this Act by a Department, or by a prescribed authority". A "prescribed authority" is defined in s 3 as:

(a) a body corporate, or an unincorporated body, established for a public purpose by, or in accordance with the provisions of, an enactment ...; or

(b) a Commonwealth-controlled company that is a prescribed authority by virtue of section $3 \mathrm{~A}$ of the Act; or

(ba) a body corporate, or unincorporated body, established by the Governor-General or by a Minister and declared by the regulations to be a prescribed authority; or

(bb) a chief executive officer of a court or tribunal; or

(c) the person holding, or performing the duties of, an office established by an enactment ...; or

(d) the person performing the duties of an appointment declared by the regulations to be an appointment the holder of which is a prescribed authority for the purposes of this Act, being an appointment made by the Governor-General, or by a Minister, otherwise than under an enactment; or

(e) an eligible case manager.

\section{An Express Power to Comment on Law-making with Implications for the Ombudsmen and Official Information Acts}

The Cabinet Manual provides that "the Office of the Ombudsmen should be consulted over the application of the Ombudsmen Act 1975 to a new agency". For example, the Ombudsmen were consulted on whether the council-controlled entities being created as part of the reform of Auckland local government should be subject to the Ombudsmen and the Official Information Acts. ${ }^{91}$

90 Seneviratne, above n 8, at 103-104.

91 See the Local Government (Auckland Transitional Provisions) Act 2010. 
The Ombudsmen should also have an express power to comment on other legislation that has implications for the Ombudsmen and Official Information Acts. Although consultation does occur, ${ }^{92}$ it is often limited to the initial stages of the legislative process, and there is no ability for the Ombudsmen to comment to select committees and/or Ministers if such consultation does not take place. An express power for Ombudsmen to comment directly to relevant Ministers and to Parliament on Bills would also prevent officials deciding whether to pass on comments made to them by Ombudsmen during consultation on the department or organisation's Bill.

\section{Recommended amendment}

Section 13 of the Ombudsmen Act should be amended to include the following new function for the Ombudsmen:

To keep under review any proposed legislation which may have implications relevant to the Ombudsmen's functions and powers under the Ombudsman Act 1975 and the Official Information Act

1992, and to advise the relevant select committee or Minister(s) where he or she sees fit.

This would not unduly fetter Parliament's sovereignty in law-making, and would obviate the need for Ombudsmen to creatively use an own motion investigation to report that the complaint could have been better resolved if a body/bodies were subject to the Ombudsmen or Official information Acts. Involving Ombudsmen also means that law-makers are better informed about any unintended consequences of the law reform impacting on the coverage of the Ombudsmen or Official Information Acts. ${ }^{93}$

\section{E Extending Jurisdiction to "Committees of the Whole" in Local Government}

Section 13(1) of the Ombudsmen Act Act provides:

92 For example, the Ombudsmen were appropriately consulted on the Immigration Bill 2007 (132-1): Interview with Beverly Wakem, Chief Ombudsmen, and officials from the Office of the Ombudsmen (Mai Chen, 3 May 2010). Clause 32(1) of that Bill provided that classified information relied on for the purpose of making any decision or determining any proceedings under the proposed Act must be kept confidential regardless of "any enactment or rule of law to the contrary." (Original subs (2)). This would have included the Ombudsmen and Official Information Acts. The Ombudsmen's submission resulted in the Transport and Industrial Relations Committee recommending that the Bill be changed so as not to limit or affect the application of the Ombudsmen and the Official Information Acts. This is now s 35(2) of the Immigration Act 2009.

93 For example, the Ombudsmen's submission on the Immigration Bill 2007 also argued that cl 32(1) of the original Bill substitute the words "classified information relied on for the purpose of making any decision or determining any proceedings under this Act must be kept confidential" in place of "used". The word "used" would capture all information that had been certified as classified, irrespective of whether it had been actually relied on to make a decision. 
$\ldots$ it shall be a function of the Ombudsmen to investigate any decision or recommendation made, or any act done or omitted, whether before or after the passing of this Act, relating to a matter of administration and affecting any person or body of persons in his or its personal capacity, ... by any committee (other than a committee of the whole) or subcommittee of any organisation named or specified in Part 3 of Schedule 1 to this Act, or by any officer, employee, or member of any such Department or organisation in his capacity as such officer, employee, or member.

The Ombudsmen do not therefore have jurisdiction to investigate administrative decisions and recommendations or acts done or omitted, by local authorities at full council meetings. However, decisions of individual council members or of a council committee (not being a "committee of the whole") may be subject to investigation. ${ }^{94}$

The reason for exempting committees of the whole from the Act is not immediately apparent from Hansard and commentary. ${ }^{95}$ But it is probably because local authorities are made up of democratically elected representatives, and often deal with policy matters. The problem is, however, as Gilling writes: ${ }^{96}$

... that as various councils operated differently, so the Ombudsman could sometimes investigate a certain problem in one body's area, but not a similar problem in another's, because in the former the issue was dealt with administratively and in the latter it was by full council decision. Such anomalies did not occur with central government.

Some councils tried to escape the Ombudsmen altogether by dealing with contentious matters in full council meetings. Files supplied were sometimes altered. Occasionally, local authorities simply did not operate as Wellington bureaucrats expected. One investigating officer was informed by a West Coast mayor that his authority had no reports by officers to the council, leaving the Ombudsman with nowhere to turn.

94 Office of the Ombudsmen Ombudsmen Quarterly Review (Vol 9:4, December 2003).

95 Hon AM Finlay, Minister of Justice, noted at the first reading of the Ombudsmen Bill (8 November 1974) 395 NZPD 5736:

I do not think there can be much argument that there is a place in local government administration for an independent investigation of citizens' complaints. The primary position of a local authority in matters affecting it is acknowledged and preserved in the legislation, but there should be no fears that this Bill is a device to increase central government control over local government.

Finlay also said at the second reading of the Bill (15 April 1975) 396 NZPD 533:

The associations representing local authorities saw some difficulty in applying the term "a matter of administration" to local body affairs ... The committee, quite correctly in my view, declined to provide a different jurisdiction test though it was strongly pressed by a number of witnesses to adopt a number of different alternatives ...

96 Gilling, above $\mathrm{n}$ 7, at 76 (emphasis added). 
Ombudsmen can effectively review council decisions anyway through preliminary recommendations, as Professor Ken A Palmer states: ${ }^{97}$

... although the ombudsmen have no power to act as a "court of appeal" or review body from the decision of a full council or board, or a committee of the whole, they have the right to investigate any preliminary recommendations made to the full body. In practice the majority of council decisions are made upon a recommendation and are vulnerable to investigation.

Understandably, Ombudsmen report frustration at having to be creative, and to telling complainants that Ombudsmen have no jurisdiction over full council meetings, especially given the significant number of complaints. ${ }^{98}$ As Ombudsman Len Castle, who was allocated specific responsibility for Local Government complaints, said: "Some complainants see no distinction between the acts and decisions of an employee, or a committee of council and the acts and decisions of a full council."199 The annual number of complaints to the Ombudsman regarding Local Government acts of administration is about $400 . .^{100}$

Allowing the Ombudsman to consider full local government council actions and decisions is also largely consistent with the ombudsmen's jurisdiction in Australia and the UK. No Australian state or territory other than Victoria has such restriction on investigating full council decisions. ${ }^{101}$ Nor does the UK's Local Government Ombudsman. ${ }^{102}$

\section{Recommended amendment}

The exemption in s 13(1) of the Act should be removed to stop abuse and to allow the Ombudsmen to act as a safety net for unintended consequences, where ratepayers have no other practical remedy.

97 Ken A Palmer Local Government Law in New Zealand (The Law Book Company, Sydney, 1993) at 89 (emphasis added).

98 Interview with Beverley Wakem, Chief Ombudsman, and officials from the Office of the Ombudsmen (Mai Chen, 3 March 2010)

99 LJ Castle "The Ombudsman's Experience with Local Government" (1982) 12 VUWLR 225 at 230.

100 There were 417 complaints in 2008/2009, 394 complaints in 2007/2008, 393 complaints in 2006/2007, and 497 complaints in 2005/2006.

101 See Ombudsman Act 2001 (Qld), s 7; Ombudsman Act 1974 (NSW), s 12; Parliamentary Commissioner Act 1971 (WA), s 14; Ombudsman Act 1978 (Tas), s 12; Ombudsman Act 1972 (SA), s 13 as compared with Ombudsmen Act 1973 (Vic), s 13.

102 See Local Government Act 1974 (UK), s 26. 


\section{F Appointment of Ombudsmen}

The controversy concerning the non-appointment of Ombudsman Nadja Tollemache for a second five year term after it was alleged she had pushed hard to gain official information from some SOEs, like Electricorp's pricing policies and top executives' salaries, ${ }^{103}$ raises the question of whether further reform is needed to strengthen the independence of the Ombudsmen office. As Buchanan writes: $:^{104}$

The system of appointments is also comparatively weak. Despite the practice of inviting applications, the process involving endorsement by party caucuses (as a prelude to a unanimous resolution of the House recommending appointment) lacks transparency and brings an element of political acceptability, rather than merit, to the appointment. The emergence of the multi-party parliaments, following New Zealand's adoption of proportional representation in 1996, tends to amplify tensions of this type and points to the need for a more open process. As discussed elsewhere in this Report, the adoption of single, non-renewable terms of office can reduce the risks surrounding officers of parliament appointments.

The Officers of Parliament Committee can operate on party lines like any of the other select committees of Parliament, despite the desirability of a cross-party environment. But there do not appear to be any better alternatives to ensure truly independent merit-based appointments, only to ensure greater independence once the Ombudsman has been appointed to the Office.

The Controller and Auditor-General is appointed for a single, fixed term, not exceeding seven years, ${ }^{105}$ and the UK Ombudsmen are appointed for a single fixed term of seven years, ${ }^{106}$ but Ombudsmen in Australia can be reappointed for a period not exceeding seven years. ${ }^{107}$

\section{Recommended amendment}

The Act should be changed to provide one fixed term of appointment for seven years for the Ombudsmen. Ombudsmen need to be able to carry out their role without fear of non-reappointment, especially if the other recommendations made in this paper for amendments to the Act are adopted. Timidity for fear of upsetting the Government will result in the Ombudsman's role atrophying. ${ }^{108}$

103 Gilling, above n 7, at 132.

104 Robert Buchanan "Commonwealth Experience II - Officers of Parliament in Australia and New Zealand: Building a Working Model" in Gay and Winetrobe, above n 60, at 86 (emphasis added).

105 Public Audit Act 2001, sch 3, cl 1.

106 Employment Equality (Age) Regulations 2006 (UK).

107 Ombudsman Act 1976, s 22.

108 Hill, above n 37, at 1078. 


\section{G Referrals from the Prime Minister}

Under s 13(5) of the Act, the Prime Minister may, with the consent of the Chief Ombudsman, refer to an Ombudsman for investigation and report back to him any matter, other than a matter concerning a judicial proceeding, which the Prime Minister considers should be investigated by an Ombudsman. The Ombudsman can then make such report to Parliament as he or she sees fit. However, the last time the Prime Minister referred a matter to an Ombudsman for investigation and report to Parliament was in April 2007, when the Prime Minister asked Ombudsman Mel Smith to investigate the administration of the criminal justice system. The Ombudsman's report to the Prime Minister on 30 November 2007 was only the fourth time the referral power has been exercised, and the first since 1983. It was also the first time there has been a comprehensive review of an entire sector.

The problem for the Ombudsmen with Prime Ministerial referrals is not to become a convenient repository for controversial political problems. Thus, previous Chief Ombudsman, Sir George Laking, refused to accept a referral of the Marginal Lands Board matter, although he accepted two other investigations instigated by the Prime Minister - one into the granting of import licences by the Department of Trade and Industry to National MP Ray La Varis in 1978, and another in 1983 into the application for rural loan finance from the Rural Bank to business magnate John Spencer. ${ }^{109}$

\section{Recommended amendment}

To safeguard the Ombudsman from any perception of acting politically or in a partisan nature through accepting controversial referrals from the Prime Minister, and to safeguard the Prime Minister from any allegations of trying to (mis)use the Ombudsmen in this way, the Act should be amended to require a resolution of Parliament before such a referral can be made to an Ombudsman.

\section{H Obstructing Ombudsman's Investigation: Increased Fine}

Section 30 of the Act makes it an offence to wilfully obstruct, hinder or resist an Ombudsman without lawful excuse, including refusing to comply with an Ombudsman's lawful requirement and making false or misleading statements, or wrongly holding out as having authority. This provision has never been used, as the Ombudsmen's Office report that talking to the Chief Executive of the department or organisation about any wilful obstruction, hindrance or resistance usually resolves the issue. A good example is in the 1997 Annual Report: ${ }^{110}$

109 (1979) AJHR A-3 at 9-10; (1983) AJHR A-3 at 3-4.

110 Office of the Ombudsmen Report of the Ombudsmen for the year ending 30 June 1997 (1997) at 38. 


\section{Withholding information may be misconduct}

The withholding of information by a Government Department may in extreme circumstances raise questions of actual misconduct by Departmental staff.

A communication between a Departmental area manager and a district solicitor was marked "privileged, not to be released" and signed by a district solicitor. The problem is that a claim of privilege is a matter which is usually given weight immediately upon its invocation. There was no possible basis on which such a claim could be made in this case.

More serious was a marginal note, by the same district solicitor, on the document which transferred matters under an Official Information Act request from the district solicitor to the area manager. The district solicitor appeared to have hand-written the following note:

'I suggest your secretary whites out what you will find ruled out by me with red biro in the ensuing 55 pages or alternatively cuts out or pastes up some messages. Page numbers could be whited out. Otherwise (the subject) will jump to the conclusion that we are keeping secrets from her and wants to go to the Ombudsman or Privacy Commissioner, or both, with resulting further waste of our valuable time'.

It was of concern to us that a legal adviser made this kind of comment to an area manager. The Department was under a legal obligation to advise a requester the kind of information being held, what the reasons for the refusal to release information were, and of their statutory right of review by an Ombudsman. We pursued this matter with the department concerned.

When the departmental CEO was told about the solicitor's wrongdoing, described above, the solicitor was dismissed. However, s 30 remains an important deterrent to obstructing the Ombudsmen, and that should be reflected in an appropriate penalty. The current fine "not exceeding \$200" was in the Act when it was enacted in 1975, and has never been updated.

\section{Recommended amendment}

At the very least, there needs to be a ten-fold increase in the fine for obstructing the Ombudsmen under s 30. Section 143 of the Human Rights Act and s 127 of the Privacy Act, which are almost identical to s 30 of the Ombudsmen Act, impose fines not exceeding $\$ 3,000$ and $\$ 2,000$ respectively.

The PA Act, which was enacted in 2001 and provides for the Office of the Auditor-General (also an officer of Parliament), provides for fines of up to $\$ 2000$ for an individual, or $\$ 5,000$ for any other person or organisation, which are ten to twenty-five times the size of the available fines under the Act.

Under s 59A of the Securities Act 1978, a person who "wilfully resists or obstructs, or deceives or attempts to deceive, any person acting in the discharge of his or her function or duties, or in the exercise of his of her powers, under [the Securities Act]" is liable on summary conviction to a fine 
not exceeding $\$ 300,000$ and, if the offence continues, to a further fine not exceeding $\$ 10,000$ for every day or part of a day during which the offence is continued.

Section 36 of the Australian Commonwealth Ombudsmen Act 1976 prescribes a penalty of $\$ 1,000$ or imprisonment for three months.

\section{FURTHER EVOLUTION OF THE OMBUDSMEN SCHEME? A Parliamentary Ombudsmen and Private Sector Complaints}

The effectiveness of the Parliamentary Ombudsmen scheme and the proliferation of private sector complaints bodies have raised issues as to whether private bodies should be allowed to adopt the name "ombudsman", and whether the Parliamentary Ombudsmen's role should be extended to include private sector complaints.

\section{B Allowing wider use of name Ombudsmen?}

In addition to Parliamentary Ombudsmen established under legislation, there are a number of other investigative and complaints bodies, formal and informal, both in New Zealand and overseas, that oversee decisions made within private sector industries (such as banking, insurance, electricity and gas, energy, water, and telecommunications) to ensure consumers are not treated unfairly by some act, omission, decision or recommendation of these industry bodies.

New Zealand has broad statutory protection for the name "Ombudsman" under s 28A of the Act, which requires the Chief Ombudsman to give written consent to any person wishing to use the name "ombudsman". This has been given twice: for the Banking Ombudsman and for the Insurance and Finance Ombudsman. ${ }^{111}$ These schemes are non-statutory, voluntary, industry-led responses to increase the perception of consumer protection within their respective industries. A similar scheme is the Electricity and Gas Complaints Commissioner. Section 158G of the Electricity Act 1992 requires every electricity distributor and retailer to participate in an approved complaints resolution scheme, and the Gazette notice of 10 December 2009 approves the Electricity and Gas Complaints Commissioner Scheme. Thus, although the scheme is not statutory, participation in the scheme is required by statute.

111 Only 11 of the 19 registered banks operating in New Zealand are members of the scheme. In accordance with s 69 of the Reserve Bank of New Zealand Act 1989, the Reserve Bank keeps a public register of banks registered in New Zealand. A list of registered banks is available on the Reserve Bank's website, "New Zealand Banks" <www.reservebank.govt.nz>. A list of participating banks in the ombudsman scheme is available at "Participating Banks" Banking Ombudsman <www.bankomb.org.nz>. 
Australia has no equivalent to s 28A of New Zealand's Act, and the term "ombudsman" has been applied to many different types of organisation. The Australian Commonwealth Ombudsman, Professor McMillan, describes the proliferation in the use of the term since 1994:112

Many local councils and universities have created an internal ombudsman, sometimes called by that name. Examples are the Sutherland Shire Council, Warringah Shire Council, Wollongong Shire Council, University of New England, and University of Technology Sydney.

Some companies - such as Westpac, Synergy and AAMI - have likewise created an internal ombudsman.

There are ombudsmen created by industry bodies, such as the Produce and Grocery Industry Ombudsman. The function of that particular office is not to resolve complaints from the public but to mediate industry disputes over the supply of produce to markets and retailers. There is a $\$ 50$ application fee to engage the services of the Ombudsman.

$\cdots$

Almost every month in the media the government is called on to create a new specialised ombudsman office. Over the last few years I have counted at least thirty such proposals, including a sports ombudsman, medical ombudsman, aged care ombudsman, superannuation ombudsman, student ombudsman, youth ombudsman, research ombudsman, crimes victim ombudsman, franchising ombudsman, arts ombudsman, motor industry ombudsman, airport ombudsman, sports doping ombudsman, gambling ombudsman - and to add colour to the list - strata title ombudsman, online auction ombudsman, grains ombudsman, drinking ombudsman (the line starts behind me), and funeral ombudsman (the line starts next door).

The gravitas of the name "Ombudsman" means that New Zealand industries seeking to establish voluntary complaints bodies have coveted the name. Industries such as water, telecommunications, private training establishments, and finance companies have discussed or tried getting authorisation for the use of the name "Ombudsman" for their complaints person.

The "Notice by the Chief Ombudsman Concerning Restrictions on the Use of the Name 'Ombudsman"' ("Notice"), issued in February 2002, sets out matters that will be taken into account in considering whether to grant a request under s 23A of the Act. The first consideration "would be to balance the public interest served by the establishment of an additional, non-parliamentary Ombudsman against the public interest in the non-proliferation of the name".

112 John McMillan "What's in a name? Use of the term "Ombudsman" (paper presented at the Australian and New Zealand Ombudsman Association, 22 April 2008) at 2. 
This is because under the Act, the term Ombudsman is "applied to an office holder who is a clearly recognisable part of the constitutional checks and balances that protect the public against excesses of executive government and thereby enhance the accountability of Ministers and officials". ${ }^{113}$ It is in the public interest not to impair that recognition, which can occur if voluntary, non-statutory "Ombudsmen" are appointed.

Second, if the Chief Ombudsman is satisfied that the public interest in establishing a nonParliamentary Ombudsman outweighs the need to avoid proliferation of the name, the request for consent will be further considered against the following factors: ${ }^{114}$

(a) The proposed use should not be in an area where an Ombudsman under the Act has or may be given jurisdiction;

(b) The scheme must meet the approval of the Chief Ombudsman to ensure that the holder of the name is able to operate effectively and independently of the persons subject to the scheme. The scheme should include provision that any modification to the scheme will require the Chief Ombudsman's consent;

(c) The holder of the name must be appointed and funded in a manner that enables him or her to operate effectively and independently of those subject to the scheme. He or she should be appointed under a publicly notified charter in plain language;

(d) The public charter should be subject to periodic public review to assess its effectiveness and credibility;

(e) The scheme should provide for complainants to make complaints free of charge direct to the 'Ombudsman', who must impartially investigate the facts and conclude with a decision on the complaint. A remedy should be provided where appropriate. The 'Ombudsman' should not be or seen to be an advocate for any party or group and must be publicly seen to be independent and impartial;

(f) The name should be associated with a function that is of a national character and application;

(g) There must be an assurance of continuing and future resources to guarantee tenure to the "Ombudsman" and his or her staff and to ensure the effective and efficient administration of the scheme; and

(h) The system and procedures used by the 'Ombudsman' must ensure fair and impartial decision making.

113 Office of the Ombudsmen Notice by the Chief Ombudsman Concerning Restrictions on the Use of the Name 'Ombudsman' (2008) at 1.

114 Ibid, at 2-3. 
The current cautious approach to allowing the name "Ombudsman" to be used should continue. Even Parliament observes this approach as recent statutory creations of independent complaints bodies such as the new Commissioner for Financial Advisors under the Financial Advisors Act 2008, or the Real Estate Agents Authority under the Real Estate Agents Act 2000, have not been named "ombudsmen", or made officers of Parliament (like the Controller and Auditor-General, although not called an Ombudsman). These complaints bodies do not play a constitutional role, but they are independent Crown Entities.

As Professor McMillan said: "The problem has more to do with unconstrained and unsystematic use of the term"; this was followed by an elaboration of the problem of public deception and public confusion. ${ }^{115}$

\section{Extending Parliamentary Ombudsmen's Jurisdiction to Private Sector Complaints?}

There is clearly a need for complaints investigation and resolution schemes in the private sector. The only question is whether the functions of the Parliamentary Ombudsmen should be extended to the private sector, thereby allowing the office to retain control of the name, while allowing the private sector to benefit from the gravitas and persuasive power of the Office.

An academic has suggested that the trend of importing the ombudsman model of dispute resolution into the private sector has resulted in the growth of large, bureaucratic institutions in the private sector, blurring the formal distinction between what is public and what is private. "The exercise by these institutions of monopolistic or oligopolistic economic powers is regarded as essentially governmental."116

A Law Honours paper has also argued that it is appropriate to extend the Parliamentary Ombudsman's jurisdiction to cover private sector injustice, as Parliamentary Ombudsmen afford the public the greatest possible protection; are appropriate for the private sector due to their independence, flexibility and credibility, that voluntary or industry-run schemes may not possess; and is a natural extension of the "private influence" that Parliament has already given to the Parliamentary Ombudsmen, given their jurisdiction under the Protected Disclosures Act 2000. ${ }^{117}$

115 Ibid, at 2 and 4. See also Reif, above n 13, at 53 and following on "Overuse of the 'Ombudsman' Title."

116 Ann Farrar "A Banking Ombudsman in New Zealand" [1992] NZLJ 320 at 326. Farrar cites the discussion by PE Morris in "The Banking Ombudsman Five Years on" [1992] Lloyd's Maritime and Commercial Law Quarterly 227 at 229-230.

117 Alastair Cameron "The Ombudsmen: Time for Jurisdictional Expansion: The Case for Extending the Jurisdiction of the Statutory Ombudsmen to cover the exercise of Public Power in the Private Sector" (2001) 32 VUWLR 549 at 561-565. 
Parliament is sovereign and can extend the Ombudsman's jurisdiction by statute to the private sector, but all of the extensions of the Ombudsmen's jurisdiction (the OIA, LGOIMA, the PDA and the COTA) have the Ombudsman playing a constitutional role in the public sector. The Ombudsman's role under the PDA focuses on serious wrongdoing in public sector organisations, and the COTA implements the Government's obligations under the Convention Against Torture and Other Cruel, Inhuman, or Degrading Treatment or Punishment 1984.

In contrast, private sector "ombudsmen" are not undertaking a constitutional role. Although, like Ombudsmen, they are independent complaints bodies, private industry ombudsmen decide disputes involving contractual interpretation rather than disputes concerning the rule of law. There may be some "public law" characteristics about the complaints handled by industry-based ombudsmen, and were it not for the rules of each scheme, they may be justiciable in an administrative law sense under s 4 of the Judicature Amendment Act 1972 and following the authority of $R v$ Panel on Takeovers and Mergers, ex parte Datafin, ${ }^{118}$ and Electoral Commission v Cameron. ${ }^{119}$

Industry ombudsmen play a vital role in ensuring consumers and businesses are treated fairly in accordance with contractual law and industry standards. The independent periodic reviews undertaken of the Banking Ombudsman have always scored highly in terms of administrative fairness and good process and efficiency as well as complainant satisfaction. ${ }^{120}$ Similarly, my work with the Electricity and Gas Complaints Commissioner has left me in admiration of the justice they manage to achieve for customers while not unleashing a flood of unreasonable claims on companies, in a very complex and difficult technical area. ${ }^{121}$

An extension of the Parliamentary Ombudsman's jurisdiction to private commercial matters misunderstands the remit of Ombudsmen as officers of Parliament to keep the executive accountable. Private sector Ombudsmen provide oversight of private sector commercial dealings, and their effectiveness is a result of the workings of the market. An industry participant that is the subject of constant complaints to an industry ombudsman is unlikely to succeed in a competitive market, such as the banking and electricity industries.

118 R v Panel on Take-overs and Mergers, ex parte Datafin [1987] QB 815 (CA).

119 Electoral Commission v Cameron [1997] 2 NZLR 421 (CA).

120 Chen \& Palmer Inaugural Periodic Process Review of the Banking Ombudsman (Wellington, 2000); Chen Palmer \& Partners Second Periodic Review of the Banking Ombudsman [For the Period 1 September 2001 - 31 October 2002] (Wellington, 2003); and Chen Palmer Third Periodic Process Review of the Banking Ombudsman (Wellington, 2006).

121 Chen Palmer Report of the Independent Review of the Electricity Complaints Commission Code of Practice: Inaugural Review After 6 Months Operation (Wellington, 2003). 


\section{KEY CONCLUSIONS AND RECOMMENDATIONS}

The Ombudsmen have built an institution over nearly 50 years which is in the main trusted and respected, and whose gravitas as a truly independent and professional office of Parliament allows them to use their persuasion to great effect in resolving complaints about matters of administration.

Just because the Ombudsmen make few formal recommendations to government departments and statutory organisations, and do not make many reports to Parliament or the Prime Minister, does not mean they are not succeeding in redressing problems with matters of administration. Indeed, Ombudsmen are sometimes more effective than courts in getting a person with a meritorious complaint substantive redress, including compensation, in a shorter timeframe. The Ombudsmen can also achieve changes to systemic failures in administrative process which no court can do. Rather than seeking public vindication through the courts, complainants (and the lawyers who advise them) need to give more consideration to making a complaint to the Ombudsmen.

The unique role of the Ombudsmen tends to turn the statistics on their head. The use of formal powers to examine any persons on oath, and to enter and inspect premises, for example, is the exception and not the rule because departments and organisations generally comply with an Ombudsman's requests. The threat of using formal statutory powers is enough to ensure compliance with an Ombudsman's requests and recommendations to redress justified complaints on matters of administration.

Thus, many of the Ombudsmen's triumphs are necessarily achieved behind closed doors, and without gloating over "wins", so that officials do not feel like scapegoats or the subject of a witchhunt. $^{122}$

A significant factor in the Ombudsmen's success in resolving complaints is their personal standing and skills in utilising their numerous statutory discretions at the right time, in the right way. To be effective, Ombudsmen also need well-tuned political antennae, to a greater extent than judges, for example. ${ }^{123}$ The energetic and necessary changes Chief Ombudsman, Beverley Wakem, and Ombudsman David McGee QC, have made to strengthen professional practice in the Ombudsmen's Office, to model good administrative practice, to assist government agencies to improve the complaints handling practices and to improve their knowledge and application of the Ombudsmen Act and of the Official Information Act, in particular, have brought the Ombudsmen's Office into the 21st Century and will help to ensure that it can effectively carry out its important constitutional role for another 50 years.

122 See Sir Guy Powles, above n 87, at 207.

123 Gavin Drewry "Ombudsmen and Administrative Law" (2009) 17 Asia Pacific Law Review 3 at 5. 
But after 50 years, it has also become clear what works, what does not work and where there are gaps and weaknesses in the system. Apart from the need to update the language of the statute to plain English drafting, substantive changes are needed to the Act to:

- $\quad$ Ensure greater independence through:

- $\quad$ a single fixed term appointment for Ombudsmen of seven years;

- changing the Prime Minister's ability to refer matters (which may be politically controversial) to Ombudsmen by requiring a resolution of Parliament (rather than from the Prime Minister alone); and

- $\quad$ an ability to keep under review (and to report to relevant Ministers and to Parliament) any proposed legislation that has implications for coverage by the Ombudsmen and Official Information Acts;

- Create a presumption that Ombudsmen have jurisdiction over all departments and organisations that exercise public power and act for a public purpose using taxpayers' money, unless bodies are specifically excluded;

- Remove the current exemption for full local council meetings, to prevent contentious matters being dealt with in full council by local authorities as a means to escape the Ombudsmen's jurisdiction;

- Expressly empower the Ombudsmen to undertake education about the Act and good process, and provide proper resourcing for this additional function, in order to:

- Facilitate prevention and cures, including of systemic maladministration issues;

- Ensure that the office is known to citizens and to Parliament and is fully utilised; and

- $\quad$ Ensure that Ombudsmen are more than a small claims court; ${ }^{124}$

- Allow the Ombudsmen to make conclusive findings of unreasonable delay by a government department, organisation or official, which would allow a complainant under certain specified enactments to escalate the matter to a "prescribed tribunal" for review;

- Place greater obligations on departments and organisations subject to the Act to respond to Ombudsmen requests for information within 20 working days, using s 29A of the OIA as a precedent, unless there is good reason to apply to the Ombudsman for an extension within 10 working days after the request, and then only for a reasonable period; and

- Consistent with the important constitutional role Ombudsmen perform, impose greater fines for actions which prevent the Ombudsmen from carrying out their functions.

124 Seneviratne, above n 8, at 324. 